J. Perinat. Med. 15 (1987) 441

\title{
Clinical aspects of antenatal glucocorticoid treatment for prevention of neonatal respiratory distress syndrome
}

\author{
Hans K. Weitzel, Uwe Lorenz, and Barbara Kipper \\ Department for Obstetrics and Gynecology, Free University of Berlin, West Ger- \\ many
}

Glucocorticoid administration to pregnant women at the appropriate time during pregnancy accelerates maturation of the fetal lung [8]. Use of such therapy is indicated in all cases in which a premature delivery is expected or medical reasons require it. This is generally necessary up to the end of the 34th week of pregnancy or in cases of detected immaturity of the lung [10].

The main indications are:

- premature contractions,

- hemorrhage during pregnancy,

- conditions of fetal distress,

- maternal diseases.

Predominant among the four main indications is the respiratory distress symdrome prophylaxis in cases of imminent premature birth. Cases of a imminent or expected premature birth frequently requires tocolysis, which involves particular problems in connection with the glucocorticoid treatment. Here it must be clarified whether the combination of tocolysis and glucocorticoid therapy does not lead to an unjustifiable endangering of the mother.

Hemorrhage during pregnancy as the indicator of an atypical placenta insertion must always be interpreted as a potential premature or early delivery risk. By conditions of fetal distress, we mean the few cases with fetal distress which still permit temporal prolongation of the delivery until the corticoid effect has been attained. There also frequently include multiple pregnancies, where delivery is usually before them.

Increasingly rare are the cases that require premature delivery for early extrauterine therapy in the fetus, as, for instance, rhesus incompatibility or surgically correctable fetal anomalies. Maternal indications for premature delivery are extremely rare in Europe and also in the United States.

We regard the following as absolute or relative contraindications:

- severe forms of preeclampsia,

- diabetes mellitus,

- premature rupture of membranes,

- maternal and/or intrauterine infections.

In our opinion, the combination of tocolysis and glucocorticoid therapy demands intensive medical surveillance, above all, strict balancing of the water equilibrium and electrolyte metabolism. Tocolysis may cause retardation of surfactant synthesis [5]. The combination with glucocorticoids appears useful.

WoLfF [15] was able to clearly demonstrate by cardiac catheter examination that the pulmonary vascular resistance cannot be considered as causal for intrapulmonary pressure increase and tendency towards edema formation, which is a possible risk under the combination therapy with tocolysis and glucocorticoids. LIGGINS [9] already emphasized in 1976 that eclampsia and preeclampsia must be regarded as a contraindication for steroid therapy. LAMONT and co-workers [7], on the other hand, saw advantages for the fetus in a glucocorticoid therapy even in the presence of severe hypertension. In any case, careful consideration is necessary in carrying out such therapy in this group of patients. If such therapy is used, strict intensive medical precautions must be taken. Otherwise, the therapy is rejected because of the high intrauterine mortality rate of the fetuses in the course of the basic disease and, in connection with a combina- 
tion therapy with tocolytics, because of the known danger of pulmonary edema. In our opinion, severe preeclampsia does not, as a rule, permit the application of a lung maturation treatment, because, with this clinical picture, it is usually of primary importance to terminate the pregnancy as quickly as possible.

RDS prophylaxis in diabetics is controversial, although it has been considered justifiable [14]. Under the steroid therapy, we observed attacks of fever above 38.5 degrees in 7 of 27 diabetic women and, in 5 of 27 , serious alterations in the glucose level and insulin requirement. Despite intensive medical treatment, one of 27 patients died of a severe pulmonary Klebsiella infection with artificial respiration.

Premature rupture of the amnion is thought to lead, via fetal stress, to an increased endogenous glucocorticoid production which in its turn reduces the incidence of RDS. In any case, BERKOwITZ [2] was able to demonstrate a decrease of RDS cases as well as an increase in the $\mathrm{L} / \mathrm{S}$ ratio after premature rupture of the amnion if this happened earlier than 16 or 24 hours in pregnancies before the 32 nd week of pregnancy. We proceed at our clinic according to the following scheme (table I).

Intrauterine infections do not as a rule permit a continuation of the endangered pregnancy.
TAESCH et al [13] point out the connection between glucocorticoid treatment and a doubling of the maternal and neonatal infection risk, particularly if the premature rupture of the amnion happened a long time before.

There are also reports to the contrary [4]. We consider it possible to perform antibiotic therapy in the mother after premature rupture of the amnion but nevertheless view this measure as extremely problematic with regard to its effect on the fetus.

On the whole, the substances have become generally accepted in clinical practice for the performance of a prenatal lung maturation treatment. These are betamethasone and dexamethasone. Alternative therapies will be discussed later at this congress. The application schemes are shown in table II.

The usefulness of an RDS prophylaxis with glucocorticoids has been confirmed by several prospective studies in the past. All investigations demonstrate a marked reduction of the RDS frequency (table III). An RDS prophylaxis should be weighed against the possible risks as a matter of principle in cases where a premature birth is to be expected. In this connection, the indication should be established all the earlier, the more immature the expected premature infant will be.

Table I. Management of premature rupture of membranes.

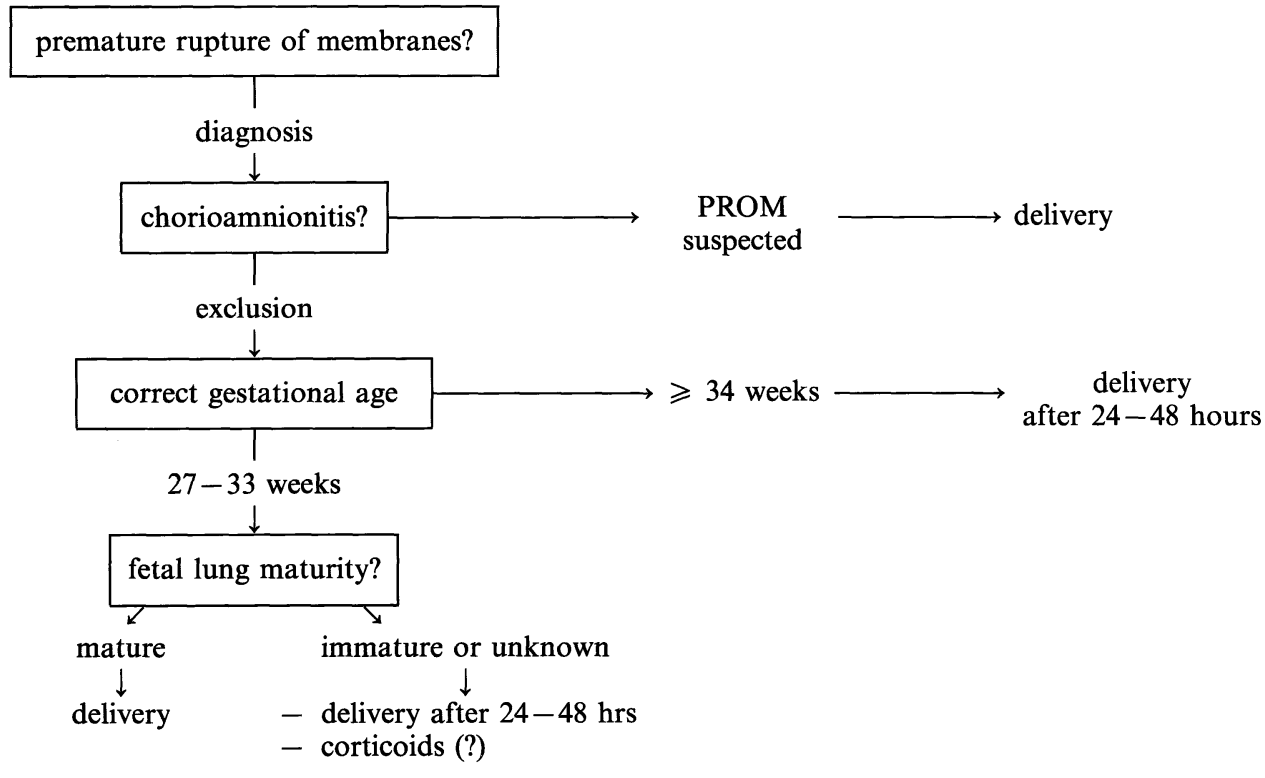


Table II. Scheme of antenatal application of glucocorticoids.

\begin{tabular}{lll}
\hline $\begin{array}{l}\text { Betamethasone } \\
\text { solubile } \\
\text { depot }\end{array}$ & $4 \times 4.0 \mathrm{mg} \mathrm{i.m.} 0 / 12 / 24 / 36 \mathrm{hrs}$ & (Ob. Gyn. Dept. Steglitz) \\
$\begin{array}{l}\text { Dexamethasone } \\
\text { depot }\end{array}$ & $2 \times 12.0 \mathrm{mg} \mathrm{i.m.} 0 / 24 \mathrm{hrs}$ & [8] \\
\hline
\end{tabular}

Detailed results are available from the Collaborative Group on Antenatal Steroid Therapy [3]. Accordingly, a particularly marked advantage is recognizable for singleton pregnancies with a reduction of RDS incidence from 18 to $12.6 \%$. Female fetuses profit in a very particular way (table IV).

The often discussed negative effects on neonatal development, particularly of the brain, have not been confirmed $[1,11,16]$.

Our own results are presented on the basis of 637 non-randomized cases from the years 1980 to 1985. In about one third of our cases, an RDS prophylaxis was carried out in underweight chil-

Table III. RDS incidence after glucocorticoid application in pregnancy; results from the literature [12].

\begin{tabular}{|c|c|c|}
\hline \multirow[t]{2}{*}{ Prospective studies } & \multicolumn{2}{|c|}{ RDS incidence } \\
\hline & $\begin{array}{l}\text { GC } \\
\text { group }\end{array}$ & $\begin{array}{l}\text { Control } \\
\text { group }\end{array}$ \\
\hline LIGGINS and HowIE, 1972 & $11.0 \%$ & $40,0 \%$ \\
\hline BLoCK et al, 1977 & $14.0 \%$ & $22,0 \%$ \\
\hline MORRISON et al, 1978 & $8.7 \%$ & $22,6 \%$ \\
\hline BALLARD et al, 1979 & $25.0 \%$ & $50,0 \%$ \\
\hline TAEUSCH et al, 1979 & $9.0 \%$ & $23,0 \%$ \\
\hline PAPAGEORgIOU et al, 1979 & $20.7 \%$ & $59,5 \%$ \\
\hline DORAN et al, 1980 & $5.0 \%$ & $18,0 \%$ \\
\hline CASPI et al, 1976 & $8.3 \%$ & $35,2 \%$ \\
\hline RAMZIN, 1978 & $8.1 \%$ & $26,4 \%$ \\
\hline
\end{tabular}

Table IV. Results of antenatal glucocorticoid therapy (dexamethasone), obtained by the Collaborative Group on Antenatal Steroid Therapy [3].

\begin{tabular}{lr} 
Incidence of RDS lower & $12.6 \%$ vs. $18.0 \%$ \\
Incidence of RDS lower & $10.1 \%$ vs. $16.0 \%$ \\
in singletons & \\
$\begin{array}{l}\text { Higher benefit of treat- } \\
\text { ment in female newborns }\end{array}$ & $\begin{array}{r}4.8 \% \text { vs. } 18.8 \% \text { : 우 } \\
\text { mes. } 14.1 \% \text { : ठ }\end{array}$ \\
\hline
\end{tabular}

Neuromotoric development not impaired dren. In the group of untreated cases, we have fewer neonatal RDS than in the treated collective, which is already an indication of the different risk grouping. One hundred ninety-four of 637 living premature infants below $2500 \mathrm{~g}$ birth weight received prophylactic treatment with betamethasone. Forty-seventy infants with RDS occurred in this group. In contrast, we had only 30 infants with RDS in 443 untreated pregnancies. This is of course due to the incomparability of the collectives.

The dependence of the therapeutic result on the sex of the newborn is also substantiated by our cases. The neonatal course of 50 boys was compared with that of 45 girls weighting $\leqslant 2000 \mathrm{~g}$ (appropriate for gestational age babies). The RDS incidence was significantly different in the two groups after a betamethasone prophylaxis. It was $1 / 25(4 \%)$ in the girls compared to $13 / 31(42 \%)$ in the boys group (table V).

Table V. Incidence of RDS according to the sex of the newborn. Significantly lower incidence of RDS in female newborns after glucocorticoid prophylaxis; $\chi^{2}=10.622$, $\mathrm{p}<0.01$.

\begin{tabular}{|c|c|c|c|c|}
\hline & \multicolumn{2}{|c|}{ With GC treament } & \multicolumn{2}{|c|}{ Without GC treatment } \\
\hline & RDS & $\varnothing \mathrm{RDS}$ & RDS & $\varnothing \mathrm{RDS}$ \\
\hline 우 & 1 & 24 & 7 & 13 \\
\hline$\sigma^{\pi}$ & 13 & 18 & 8 & 11 \\
\hline
\end{tabular}

If we check in our data the effectiveness of a betamethasone treatment, we see that, both in the collective of the Heidelberg University Clinic [6] and in our own cases, a marked reduction of the RDS incidence was only detectable after betamethasone therapy as of the 32nd week of pregnancy (table VI). Up to that time, nearly every second child develops a respiratory distress syndrome despite RDS prophylaxis, the severe forms of stages III and IV predominating, but after corticoid 
Table VI. Incidence of neonatal RDS after betamethasone treatment in pregnancy in correlation to gestational age at birth; comparison of two university departments.

\begin{tabular}{|c|c|c|c|c|c|c|c|c|}
\hline \multirow{2}{*}{$\begin{array}{l}\text { Weeks of } \\
\text { pregnancy }\end{array}$} & \multicolumn{4}{|c|}{ Ob. Gyn. Dept. Heidelberg } & \multicolumn{4}{|c|}{ Ob. Gyn. Dept. Berlin-Steglitz } \\
\hline & $\begin{array}{l}\mathrm{N} \\
\text { Children }\end{array}$ & $\begin{array}{l}\mathrm{N} \\
\text { Without } \\
\text { RDS }\end{array}$ & $\begin{array}{l}\mathrm{N} \\
\text { With } \\
\text { RDS }\end{array}$ & $\begin{array}{l}\% \\
\text { RDS }\end{array}$ & $\begin{array}{l}\mathrm{N} \\
\text { Children }\end{array}$ & $\begin{array}{l}\mathrm{N} \\
\text { Without } \\
\text { RDS }\end{array}$ & $\begin{array}{l}\mathrm{N} \\
\text { With } \\
\text { RDS }\end{array}$ & $\begin{array}{l}\% \\
\text { RDS }\end{array}$ \\
\hline$<30+0$ & 18 & 9 & 9 & $50 \%$ & 22 & 7 & 15 & $68 \%$ \\
\hline $\begin{array}{l}30 \pm 0 \\
31+6\end{array}$ & 21 & 11 & 10 & $48 \%$ & 36 & 27 & 9 & $25 \%$ \\
\hline $\begin{array}{l}32 \pm 0 \\
33+6\end{array}$ & 35 & 26 & 9 & $26 \%$ & 50 & 34 & 16 & $32 \%$ \\
\hline $\begin{array}{l}34 \pm 0 \\
35+6\end{array}$ & 21 & 21 & - & - & 58 & 52 & 6 & $10 \%$ \\
\hline \multirow[t]{2}{*}{$\geqslant 36+0$} & 17 & 17 & - & $=$ & 28 & 27 & 1 & $3 \%$ \\
\hline & 112 & 84 & 28 & & 194 & 147 & 47 & \\
\hline
\end{tabular}

Table VII. Distribution of RDS grade I-IV with and without antenatal corticoid therapy. Higher incidence of RDS specific mortality and more severe grades of RDS in the untreated group; $\chi^{2}=7.744, \mathrm{p}<0.05$.

\begin{tabular}{lllll}
\hline RDS & $\begin{array}{l}\text { With } \\
\text { GC } \\
\text { treatment }\end{array}$ & $\begin{array}{l}\dagger \\
\text { due to } \\
\text { RDS }\end{array}$ & $\begin{array}{l}\text { Without } \\
\text { GC } \\
\text { treatment }\end{array}$ & $\begin{array}{l}\dagger \\
\text { due to } \\
\text { RDS }\end{array}$ \\
\hline I & 6 & 1 & 1 & - \\
II & 4 & - & 2 & - \\
III & 2 & - & 6 & 1 \\
IV & 2 & - & 6 & 4 \\
\hline & 14 & 1 & 15 & 5 \\
\hline
\end{tabular}

\section{Summary}

Main indications for antenatal administration glucocorticoid to pregnant women are premature contractions, hemorrhage during pregnancy, conditions of fetal distress and maternal diseases. There are some absolute or relative contraindications as well: severe forms of preeclampsia, diabetes mellitus, premature rupture of membranes, maternal and/intrauterine infections.

In a retrospective evaluation of the data obtained at our institution of 637 nonrandomized cases from the years $1980-1985$, we could demonstrate the dependence of the therapeutic results on the sex of the newborn. The RDS incidence is significantly different after betamethasone prophylaxis. It was $1 / 25(4 \%)$ in girls compared to $13 / 31(42 \%)$ in boys. treatment a change towards less severe stages (I and II) can be shown and the mortality due to RDS (III and IV) is remarkably lower (table VII).

Conclusions: We recommend RDS prophylaxis for all premature contractions between the 32nd and 34 th week of pregnancy inclusively. In addition, it should be given in cases of confirmed lung immaturity. Special restrictions are necessary in cases of preeclampsia, eclampsia, diabetes and confirmed maternal infections. In the group of diabetics or preeclamptic patients, an RDS prophylaxis should only be given, if at all, when it can be performed under intensive medical conditions.

A marked reduction of the RDS incidence is only detectable after betamethasone therapy from the 32nd to the 34th week of gestation. Thus we recommend RDS prophylaxis for all patients with premature contraction, mainly between the 32nd and 34th week of pregnancy. In addition, it should be given in cases of confirmed lung immaturity. Special restrictions are necessary in cases of preeclampsia, eclampsia, diabetes and confirmed maternal infections. In the group of diabetes or preeclampsia patients an RDS prophylaxis should only be given, if at all, when it can be performed under intensive care conditions.

Keywords: Antenatal glucocorticoid treatment, prematurity, prevention of neonatal respiratory distress syndrome. 


\section{Zusammenfassung}

Klinische Aspekte der antepartalen Glukokortikoidbehandlung zur Prävention des Atemnotsyndroms des Neugeborenen

Die hauptsächlichen Indikationen zur antepartalen Glukokortikoidgabe an schwangere Frauen sind vorzeitige Wehen, Blutungen in der Spätschwangerschaft, fetal distress and mütterliche Erkrankungen. Andererseits gibt es einige absolute bzw. relative Kontraindikationen: Schwere Formen der Präeklampsie, insulinpflichtiger Diabetes mellitus, vorzeitiger Blasensprung sowie mütterliche bzw. fetale uterine Infektionen.

In einer retrospektiven Auswertung der Daten, die an der Frauenklinik des Klinikums Berlin-Steglitz an 637 nicht randomisierten Fällen in den Jahren 1980 bis 1985 erhalten wurden, konnten wir die Abhängigkeit des therapeutischen Effektes der Kortikoidbehandlung vom Geschlecht des Neugeborenen nachweisen. Die Inzidenz des Atemnotsyndroms ist signifikant unterschiedlich nach Betamethasonprophylaxe: Sie betrug 1/25 (4\%) bei Mädchen, verglichen zu 13/31 (42\%) bei Knaben.

Eine deutliche Reduktion der Inzidenz des Atemnotsyndroms ließ sich nur nach Betamethasontherapie zwischen der 32. bis zur 34. SSW nachweisen. Deshalb empfehlen wir die RDS-Prophylaxe für alle Patientinnen mit vorzeitiger Wehentätigkeit insbesondere zwischen der 32. und 34. SSW. Außerdem sollten Glukokortikoide gegeben werden bei allen Fällen mit durch Fruchtwasseranalyse gesicherter zu erwartender Lungenunreife. Spezielle Vorsichtsmaßnahmen sind notwendig in Fällen von Präemklampsie, Eklampsie, Diabetes und gesicherter mütterlicher Infektion. In der Gruppe der Diabetikerinnen oder Präeklampsiepatientinnen darf eine RDSProphylaxe nur dann durchgeführt werden, wenn dies unter intensivmedizinischen Bedingungen geschehen kann.

Schlüsselwörter: Antepartale Glukokortikoidbehandlung, fetale Unreife, Prävention des Atemnotsyndroms bei Neugeborenen.

\section{Résumé}

Aspects cliniques du traitement anténatal par glucocorticoides pour la prévention du SDR neonatal

Les indications principales du traitement anténatal par glucocorticoïdes chez la femme enceinte sont les contractions prématurées, les hémorragies de la grossesse, les situations de souffrances foetales et les maladies maternelles. Il existe certaines contre-indications absolues ou relatives: prééclampsie sévère, diabète sucré, rupture prématurée des membranes, infections maternelles et intrautérines.

Dans l'évaluation rétrospective des données obtenues dans notre institution concernant 637 cas non randomisés de 1980 à 1985, nous avons pu démontrer que les résultats de la thérapeutique dépendent du sexe du nouveau-né. L'incidence du SDR est significativement différente après prophylaxie par bétaméthazone. Elle est de $1 / 25(4 \%)$ chez les filles et en comparaison de $13 / 31$ $(42 \%)$ chez les garçons.

On ne détecte une diminution nette de l'incidence du SDR après traitement par bétaméthazone qu'entre 32 et 34 semaines. Aussi, nous recommendons une prophylaxie du SDR pour toutes les patientes ayant des contractions prématurément, particulièrement entre 32 et 34 semaines. En outre, cette prophylaxie devrait être proposée en cas d'immaturité pulmonaire confirmée. Des limitations spéciales sont necessaires en cas de préeclampsie, d'éclampsie, de diabète et d'infection maternelle confirmée. Dans le groupe des patiente préeclampsiques ou diabétiques on ne devrait proposer une prophylaxie du SDR que si alle peut être réalisée, environnée de soins intensifs.

Mots-clés: Prématurité, prévention du syndrome de détresse respiratoire néonatale, traitement anténatal par glucocorticoïdes.

\section{References}

[1] BeCK JC, W Mitzner, JWC Johnson, GM HutCHINS, JM FoIdART, WT LONDON, AE PALMER, R ScotT: Betamethasone and the rhesus fetus: effect on lung morphometry and connective tissue. Pediatr Res 15 (1981) 235

[2] BERKowItz RL, BW BONTA, JE WARshaw: The relationship between premature rupture of the membranes and the respiratory distress syndrome. Am J Obstet Gynecol 124 (1976) 712
[3] Collaborative Group on Antenatal Steroid TheraPy, Division of Lung Diseases, National Institute of Health: Effect of antenatal dexamethasone administration on the prevention of respiratory distress syndrome. Am J Obstet Gynecol 141 (1981) 276

[4] Curet LB, JC Morrison, A Vijaya Rao, the Collaborative Group on Antenatal SteroID TherAPY: Antenatal therapy with corticosteroids and 
postpartum complications. Am J Obstet Gynecol 152 (1985) 83

[5] Dudenhausen JW, G Kynast, AM Lange-LindBERG, E SALING: Influence of long-term beta-mimetic therapy on the lecithin content of amniotic fluid. Gynecol Obstet Invest 9 (1978) 205

[6] KÜHN W, U LORENZ, H RÜTTGERS, F Kubli: Vorbeugende Behandlung des Atemnotsyndroms des Neugeborenen durch antepartale Glukokortikoidgabe (Betamethason). Geburtshilfe Frauenheilkd 44 (1984) 315

[7] LAmont RF, PDM Dunlop, MI Levene, MG ELDER: Use of glucocorticoids in pregnancies complicated by severe hypertension and proteinuria. $\mathrm{Br}$ J Obstet Gynecol 90 (1983) 199

[8] LigGINS GC, RN HowIE: A controlled trial of antepartum glucocorticoid treatment for prevention of the respiratory distress syndrome in premature infants. Pediatrics 50 (1972) 515

[9] LigGINs GC: Prenatal glucocorticoid treatment: Prevention of respiratory distress syndrome. In: MOORE TD (ed): Lung maturation and the prevention of hyaline membrane disease, Report of the 70th Ross Conference on Pediatric Research. Ross Laboratories, Columbus, Ohio 1976

[10] LORENZ U: Antepartale Lungenreifebestimmung durch Fruchtwasseranalyse. Springer-Verlag, Berlin - Heidelberg - New York 1982

[11] Mac Arthur BA, RN Howie, JA Dezoete, J ElKINS: Cognitive and psychosocial development of 4-year-old children whose mothers were treated antenatally with betamethasone. Pediatrics 68 (1981) 638

[12] RAMzIN MS: Kortikoide zur Förderung der Lungenreife. Gynäkologe 15 (1982) 145

[13] Taeusch HW, F Frigoletto, J Kitzmiller, ME Avery, A Hehre, B Fromm, E LAWSON, RK NEFF: Risk of respiratory distress syndrome after prenatal dexamethasone treatment. Pediatrics 63 (1979) 64

[14] Weitzel HK, D Benthin, W BurkerT, K Gleibe, HJ MitzKaT: Komplikationen nach Glucocorticoidgabe bei diabetischen Schwangeren. In: :SchmidT E, JW Dudenhausen, E Saling (eds): Perinatale Medizin, Bd VIII. Georg-Thieme-Verlag, Stuttgart 1981

[15] WolfF F, U MeIER, A BoltE: Untersuchungen zum Pathomechanismus schwerer kardiopulmonaler Komplikationen unter tokolytischer Behandlung mit $\beta$-adrenergen Substanzen und Betamethason. $\mathbf{Z}$ Geburtshilfe Perinatol 183 (1979) 343

[16] Wong YC, CS BeardSMORE, M Silverman: Antenatal dexamethasone and subsequent lung growth Arch Dis Child 57 (1982) 536

Hans K. Weitzel, M. D.

Professor and Director

Department of Obstetrics and Gynecology

University Hospital Steglitz

Hindenburgdamm 30

1000 Berlin 45, West Germany 